\title{
Evidence for suboxic nitrification in recent marine sediments
}

\author{
Robert J. G. Mortimer ${ }^{1, *}$, Michael D. Krom ${ }^{1}$, Sansha J. Harris ${ }^{1}$, Peter J. Hayes ${ }^{2}$, \\ Ian M. Davies ${ }^{2}$, William Davison ${ }^{3}$, Hao Zhang ${ }^{3}$ \\ ${ }^{1}$ School of Earth Sciences, University of Leeds, Leeds LS2 9JT, United Kingdom \\ ${ }^{2}$ Fisheries Research Services, Marine Laboratory, PO Box 101, Victoria Road, Aberdeen AB11 9DB, United Kingdom \\ ${ }^{3}$ Environmental Science Department, Institute of Environmental and Natural Sciences (IENS), Lancaster University, \\ Lancaster LA1 4YQ, United Kingdom
}

\begin{abstract}
The classical scheme of biogeochemical zones (BGZ) is known to be an oversimplification of the microbial processes that occur in organic-rich marine sediments. Results from a coupled deployment of pore-water gel probes in Loch Duich, Scotland, provide direct evidence for rapid recycling within the iron reduction (FeR) and sulphate reduction (SR) zones. High resolution porewater profiles obtained using diffusive equilibrium in thin films (DET) gel probes found a nitrate peak at the boundary between the FeR and SR zones. This non-steady state feature is consistent with recycling of reduced $\mathrm{N}$ occurring throughout the FeR zone. Both conventional pore-water iron profiles and results from diffusive gradient in thin films (DGT) probes indicate that iron is solubilised and precipitated in rapid Fe/S recycling reactions throughout the SR zone. The presence of such complex recycling reactions confirms the oversimplification of the classical BGZ scheme.
\end{abstract}

KEY WORDS: Biogeochemical recycling $\cdot$ Suboxic nitrification $\cdot$ DET $\cdot$ DGT

\section{INTRODUCTION}

Biogeochemical zones (BGZ) form the framework for describing the early diagenesis of aquatic sediments. They represent degradation of organic matter by bacteria using successively less energy-efficient terminal electron accepting processes (TEAPs). Evidence for the existence of these sequential processes has been known for more than half a century (e.g. Mortimer et al. 1941), but a formalised depth-related scheme was not developed until the 1970s (e.g. Claypool \& Kaplan 1974, Froelich et al. 1979). During the last $20 \mathrm{yr}, \mathrm{BGZ}$ have been used to describe a wide variety of aquatic environments where the supply of labile organic matter exceeds diffusion of oxygen into the sediment, from hypertrophic systems (e.g. Barica \& Mur 1980) to the oligotrophic deep ocean (e.g. Froelich et al. 1979). The depth range of each zone is determined from a charac-

*E-mail: r.mortimer@earth.leeds.ac.uk teristic sequence of chemical changes in the sediment pore-water (Jørgensen 1983).

During the last decade, research has begun to indicate that sequential BGZ are an oversimplification of the biogeochemical processes occurring in sediments (e.g. Canfield et al. 1993, Coleman et al. 1993, Postma \& Jackobsen 1996). Concomitantly, new advances in sampling pore-water geochemistry (e.g. Davison et al. 1991, 1994, Krom et al. 1994, Brendel \& Luther 1995, Zhang et al. 1995, Mortimer et al. 1998, Kjaer et al. 1999) have begun to reveal new biogeochemical interactions (e.g. Luther et al. 1997).

In this paper, we present results from the first simultaneous field deployment of 2 of these new technologies, diffusive equilibrium in thin films (DET) gel probes (Davison et al. 1994, Krom et al. 1994, Mortimer et al. 1998) and diffusive gradient in thin films (DGT) probes (Zhang et al. 1995). These results show new pore-water features, and direct evidence for complex recycling processes within the iron reduction (FeR) and sulphate reduction (SR) zones. 


\section{MATERIALS AND METHODS}

An undisturbed box core was collected from a depth of $120 \mathrm{~m}$ in the centre of Loch Duich, a marine fjord on the west coast of Scotland, in April 1997. Three DET gel probes and 1 DGT gel probe were inserted and left for $24 \mathrm{~h}$. DET probes consist of a perspex spear containing a thin $(0.5$ to $1 \mathrm{~mm})$ strip of polyacrylamide gel which equilibrates with the pore-water chemistry and can then be analysed at mm resolution. The DGT technique uses a perspex probe containing a strip of chelex resin with a diffusive gel layer in front (Zhang et al. 1995).
Metal ions diffuse through the gel layer and bind to the chelex, allowing a depth profile of metal flux to be obtained (Zhang et al. 1995). The probes were sampled and analysed using standard procedures (Zhang et al. 1995, Mortimer et al. 1998) to obtain high-resolution pore-water chemistry. A subcore was then taken from the central undisturbed portion of the box core to obtain conventional pore-water samples for comparison. This core was sliced inside a $\mathrm{N}_{2}$-filled glovebox, centrifuged and the supernatant filtered through a $0.45 \mu \mathrm{m}$ filter. The samples were analysed for $\mathrm{NH}_{4}{ }^{+}$using a flow injection analyser (Hall \& Aller 1992); for $\mathrm{Cl}^{-}, \mathrm{NO}_{3}^{-}$and
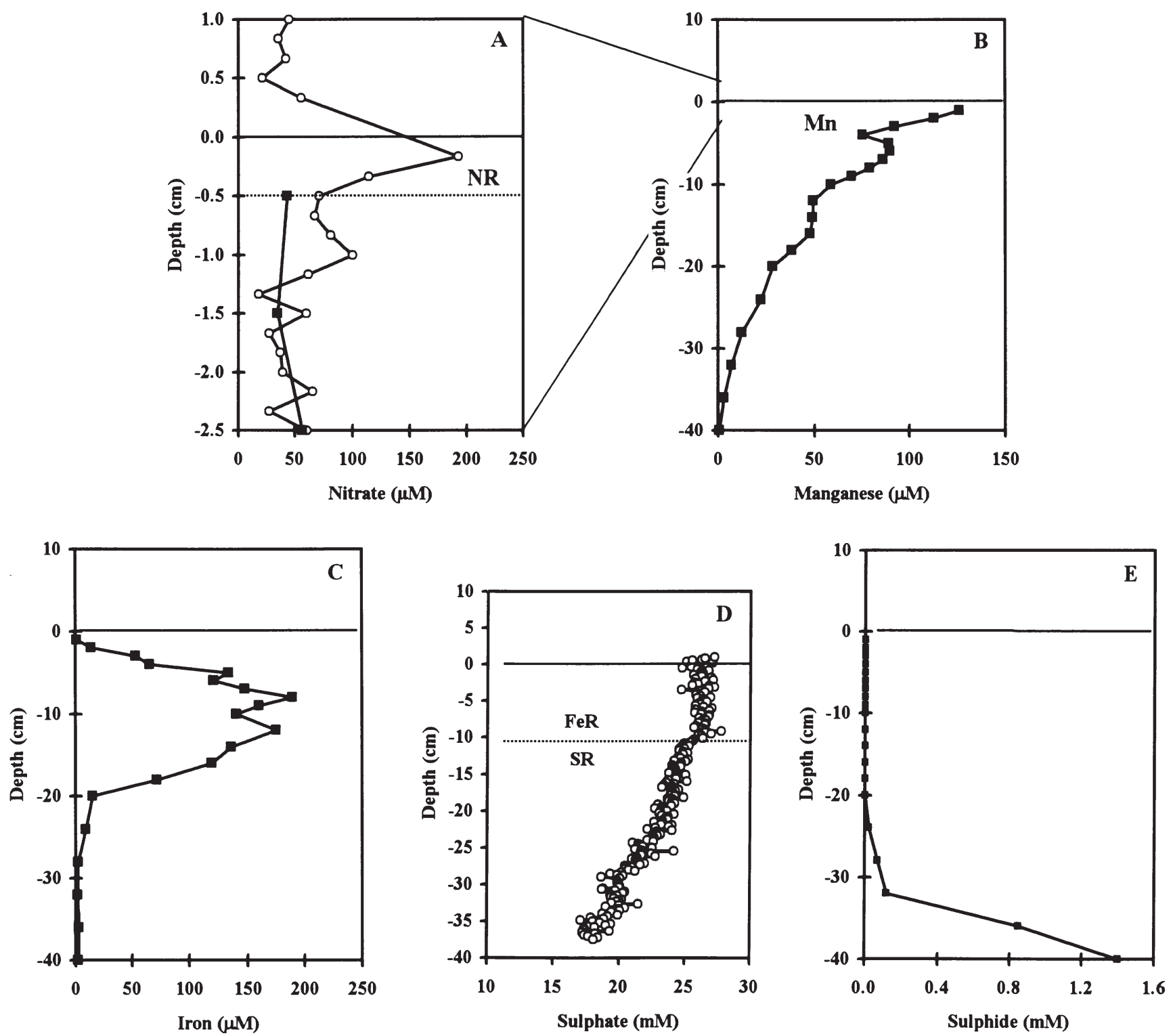

Fig. 1. Pore-water profiles of nitrate (A), manganese (B), iron (C), sulphate (D) and sulphide (E) in Loch Duich. Labels indicate position of biogeochemical zones ( $\mathrm{NR}, \mathrm{MnR}, \mathrm{FeR}, \mathrm{SR}=$ nitrate, manganese, iron and sulphate reduction, respectively). Note the different depth scale for nitrate (only upper $2.5 \mathrm{~cm}$ shown). (O) DET gel profiles and ( $\square$ ) conventional pore-water profiles obtained by core slicing are indicated 
$\mathrm{SO}_{4}{ }^{2-}$ using a Dionex DX100 Ion Chromatograph with an AS14 column; for $\mathrm{S}^{2-}$ using the methylene blue method; and for $\sum F$ e using a Perkin-Elmer Zeeman 4100 ZL atomic absorption spectrometer.

\section{RESULTS AND DISCUSSION}

\section{Biogeochemical zones}

The sediments of Loch Duich show the classical sequence of biogeochemical zones (Fig. 1). The conven- tional core profile for nitrate did not resolve any structure, but in the high resolution DET gel profile there was a decrease from a maximum immediately below the sediment surface due to coupled nitrification-denitrification (Fig. 1A). There was a peak of Mn immediately below the sediment water interface which decreased due to precipitation of $\mathrm{Mn}^{2+}$ at depth (Fig. 1B; Krom \& Sholkovitz 1978). The Fe concentration increased down-core to a peak of approximately $190 \mu \mathrm{M}$ at a depth of $10 \mathrm{~cm}$, which delineates the base of the iron reduction (FeR) zone (Fig. 1C). The sulphate concentration was constant throughout the FeR zone (down to $10 \mathrm{~cm}$ ), but then decreased below $10 \mathrm{~cm}$ (top of the SR zone) (Fig. 1D). As has been observed previously (e.g. Goldhaber et al. 1974), there was no measurable sulphide in the upper part of the SR zone (10 to $20 \mathrm{~cm}$ ), presumably due to removal by uptake on labile Fe oxides and precipitation with $\mathrm{Fe}^{2+}$ (Canfield et al. 1993). When labile Fe oxides were depleted $(>25 \mathrm{~cm})$, free dissolved sulphide accumulated in the porewaters (Fig. 1E)

\section{Nitrate peak within the suboxic zone}

The complete depth profile of nitrate shows a striking non steadystate peak at a depth of $10 \mathrm{~cm}$, the boundary between the FeR and SR zones (Fig. 2B). This peak was up to $900 \mu \mathrm{M}$ and defined by 6 gel samples spread over a depth of $0.5 \mathrm{~cm}$ and a single point in the $0.5 \mathrm{~cm}$ spaced conventional measurements.

The presence of this nitrate peak at the FeR-SR boundary within Loch Duich sediments was confirmed by a subsequent re-deployment of a nitrate DET probe at the same site in May 2000. This time, analysis was performed using the standard colorimetric method (Strickland \& Parsons 1972), modified for small samples (Harris et al. in press), resulting in a lower detection limit $(0.25 \mu \mathrm{M})$ and increased precision (relative $\mathrm{SD}<4 \%$ ). A large nitrate peak was again found exactly at the
Fig. 2. Pore-water profiles of ammonia-N (A), nitrate $(B, C)$ and DGT iron (D) in Loch Duich. Labels indicate position of iron and sulphate reduction zones (FeR and $\mathrm{SR}$, respectively) as determined from relevant pore-water profiles 
FeR-SR boundary (Fig. 2C). We have measured nitrate profiles in 11 cores from Loch Duich over 3 sampling trips and have found large suboxic nitrate peaks in 2 and smaller peaks in a further 4 .

A possible explanation for this nitrate peak is the presence of macrofaunal burrows (cf. Mortimer et al. 1999). This is considered implausible here because the nitrate peak was present in both the gel sample and conventional sample at approximately the same depth, yet these samples were horizontally separated by several $\mathrm{cm}$ in the box core. It is considered extremely unlikely that a burrow would have intersected these samples at the same depth and at no other. Furthermore, if the sediment contained macrofauna capable of introducing enough oxygen to trigger conventional nitrification at a depth of $10 \mathrm{~cm}$, it would be expected to cause a minimum in the ammonia-N profile (Luther et al. 1998, Mortimer et al. 1999) which was not observed (Fig. 2A).

The presence of high nitrate concentrations at the onset of the SR zone shows that microbial nitrification was occurring deep within the anaerobic layers. This confirms other recent work that has shown that nitrification can occur in suboxic sediments (e.g. Luther et al. 1997, 1998, Hulth et al. 1999). The most likely explanation is that there was recycling of reduced $\mathrm{N}$ occurring throughout the FeR zone. Since the nitrate peak is at the base of the FeR zone, it is tempting to postulate that sub-oxic nitrification occurred by oxidation of ammonia with $\mathrm{Fe}$ oxyhydroxides. However, Luther et al. $(1997,1998)$ calculated that nitrification of ammonia with $\mathrm{Fe}$ oxides is not thermodynamically possible, although their calculation used crystalline goethite rather than the labile Fe oxyhydroxides which are the reactive phase at this depth zone. Instead, they provided indirect evidence for coupling between the $\mathrm{Mn}$ and $\mathrm{N}$ cycles whereby $\mathrm{Mn}^{2+}$ was oxidised by nitrate (Eq. 1) and of oxidation of ammonia by Mn oxides (Eq. 2) (Luther et al. 1997, 1998).

$$
\begin{aligned}
& 5 \mathrm{Mn}^{2+}+2 \mathrm{NO}_{3}{ }^{-}+4 \mathrm{H}_{2} \mathrm{O} \rightarrow 5 \mathrm{MnO}_{2}+\mathrm{N}_{2}+8 \mathrm{H}^{+} \\
& 3 \mathrm{MnO}_{2}+2 \mathrm{NH}_{3}+6 \mathrm{H}^{+} \rightarrow 3 \mathrm{Mn}^{2+}+\mathrm{N}_{2}+6 \mathrm{H}_{2} \mathrm{O} \\
& 4 \mathrm{MnO}_{2}+\mathrm{NH}_{4}^{+}+6 \mathrm{H}^{+} \rightarrow 4 \mathrm{Mn}^{2+}+\mathrm{NO}_{3}{ }^{-}+5 \mathrm{H}_{2} \mathrm{O}
\end{aligned}
$$

In our sediments, nitrification by $\mathrm{MnO}_{2}$ (Eq. 3) could have occurred throughout the FeR zone, causing the observed conventional Mn (II) profile (Fig. 1B). Excess labile $\mathrm{MnO}_{2}$ has been determined within the FeR zone in this location (Burns 1996). Throughout most of the FeR zone, any nitrate produced was immediately denitrified to $\mathrm{N}_{2}$ which accounts for the low observed concentrations.

This coupled nitrification-denitrification mechanism would result in reduced accumulation of ammonia- $\mathrm{N}$ in the FeR zone compared to the SR zone and is there- fore consistent with the observed change in gradient of the ammonia-N profile at $10 \mathrm{~cm}$ depth (Fig. 2A). By this mechanism, the nitrate peak is attributed to a selective inhibition of the denitrification part of the couple, possibly by local production of sulphide or diffusion up from the SR zone below. Denitrification is known to be more susceptible than nitrification to inhibition by sulphide (Jørgensen 1983, Sørensen 1987).

Since the nitrate peak is so sharp, the process must be transient and non-steady state. One mechanism is that it is caused by boundary effects between an upper region of $\mathrm{Mn} / \mathrm{N}$ cycling and a lower region of $\mathrm{Fe} / \mathrm{S}$ cycling (see below). An alternative mechanism is that a sediment slump has occurred, burying a thin horizon of Mn oxides to a depth of $10 \mathrm{~cm}$. Whilst the pore-waters have had time to equilibrate, there is sufficient $\mathrm{Mn}$ oxide in the sediment to significantly increase suboxic nitrification within this narrow zone. This in turn drives higher rates of denitrification immediately above and below the peak. Both of these mechanisms are nonsteady state effects and are caused by a perturbation of the suboxic nitrification-denitrification couple.

\section{Iron-sulphur recycling}

The Fe profile obtained using the DGT probe shows that rapid recycling of $\mathrm{Fe}$ and $\mathrm{S}$ was also occurring in the SR zone (Fig. 2D) (Krom et al. unpubl.). The DGT Fe profile increases towards the base of the FeR zone. Assuming that the FeR rate decreases exponentially with depth, this increase may be due to decreasing rates of Fe removal. Alternatively, there may be a gradual increase in SR within the FeR zone, with the sulphide produced reacting with Fe minerals to produce more dissolved iron. At the FeR-SR boundary, there is a minimum in the DGT-Fe profile due to nonsteady state iron removal. Below the boundary, the DGT Fe decreases through the SR zone. This may be caused by a decrease in SR rates, producing less sulphide to react with $\mathrm{Fe}$ minerals, or to a decrease in the availability of reactive Fe minerals to react with any sulphide produced.

\section{Significance}

The existence of complex recycling reactions suggests that our understanding of sedimentary biogeochemical processes is far from complete. The original BGZ scheme relied on specific groups of bacteria using a single electron acceptor in a particular zone. However, it has been shown that bacteria are capable of switching between different electron acceptors (Sørensen 1982, 1987, Coleman et al. 1993, Dollhopf et 
al. 2000). FeR and SR can also occur concomitantly (Jacobson 1994, Postma \& Jakobsen 1996).

Luther et al. $(1997,1998)$ suggested that the cycles of $\mathrm{Mn}$ and $\mathrm{N}$ should not be viewed separately, but as inherently linked. Direct evidence for coupling between these 2 cycles was recently obtained in laboratory experiments by Hulth et al. (1999). They showed that $\mathrm{Mn}$ reduction could be coupled to anoxic nitrification (Eq. 3) and that the latter would not always be evident in pore-waters due to rapid coupled denitrification. Our results from Loch Duich provide direct field evidence for similar reactions occurring throughout the FeR zone, as well as for an additional complex coupling of the Fe and S cycles in the SR zone.

Acknowledgements. The authors would like to acknowledge the assistance of the captain and crew of the FRV 'Clupea', and Lucy Burns, Paula Kerr and Michael Spence who helped with sampling. This work was supported by Leverhulme Trust grant F/122/BF to R.J.G.M. and M.D.K.

\section{LITERATURE CITED}

Barica J, Mur LR (eds) (1980) Hypertrophic ecosystems: developments in hydrobiology, Vol 2. Dr. W. Junk BV Publishers, The Hague

Brendel PJ, Luther GW III (1995) Development of a gold amalgam voltammetric microelectrode for the determination of dissolved iron, manganese, $\mathrm{O}_{2}$, and $\mathrm{S}$ (-II) in porewaters of marine and freshwater sediments. Environ Sci Tech 29: 751-761

Burns LJ (1996) Metal partitioning in recent sediments. MSc thesis, University of Leeds

Canfield DE, Thamdrup B, Hansen JW (1993) The anaerobic degradation of organic oatter in Danish coastal sediments: iron reduction, manganese reduction, and sulfate reduction. Geochim Cosmochim Acta 57:3867-3883

Claypool GE, Kaplan IR (1974) The origin and distribution of methane in marine sediments. In: Kaplan IR (ed) Natural gases in marine sediments. Plenum, New York, p 99-139

Coleman ML, Hedrick DB, Lovley DR, White DC, Pye K (1993) Reduction of $\mathrm{Fe}(\mathrm{III})$ in sediments by sulphate-reducing bacteria. Nature 361:436-438

Davison W, Grime GW, Morgan JW, Clarke K (1991) Distribution of dissolved iron in sediment pore waters at submillimetre resolution. Nature 352:323-324

Davison W, Zhang H, Grime GW (1994) Performance characteristics of gel probes used for measuring pore waters. Environ Sci Tech 28:1623-1632

Dollhopf ME, Nealson KH, Simon D, Luther GW III (2000) Kinetics of Fe (III) and Mn (IV) reduction by Black Sea strains of Shewanella putrefaciens using in situ solid state voltammetric $\mathrm{Au} / \mathrm{Hg}$ electrodes. Mar Chem 70:171-180

Froelich PN, Klinkhammer GP, Bender ML, Luedtke NA and 6 others (1979) Early oxidation of organic matter in pelagic sediments of the Eastern Equatorial Atlantic: suboxic diagenesis. Geochim Cosmochim Acta 43:1075-1090

Goldhaber MB, Aller RC, Cochran JK, Rosenfeld JK, Martens CS, Berner RA (1977) Sulfate reduction, diffusion, and bio-

Editorial responsibility: Otto Kinne (Editor),

Oldendorf/Luhe, Germany turbation in Long Island Sound sediments: report of the FOAM group. Am J Sci 277:193-237

Hall POJ, Aller RC (1992) Rapid, small volume flow injection analysis for $\sum \mathrm{CO}_{2}$ and $\mathrm{NH}_{4}{ }^{+}$in marine and freshwaters. Limnol Oceanogr 37:1113-1119

Harris SJ, Mortimer RJG (in press) Determination of nitrate in small volume samples $(100 \mu \mathrm{l})$ of seawater by the cadmium-copper reduction method. Int J Environ Anal Chem

Hulth S, Aller RC, Gilbert F (1999) Coupled anoxic nitrification/manganese reduction in marine sediments. Geochim Cosmochim Acta 63:49-66

Jacobson ME (1994) Chemical and biological mobilization of Fe (III) in marsh sediments. Biogeochemistry 25:41-60

Jørgensen BB (1983) Processes at the sediment-water interface. In: Bolin B, Cook RB (eds) The major biogeochemical cycles and their interactions. SCOPE, Wiley, New York, p 477-509

Kjaer T, Larsen LH, Revsbech NP (1999) Sensitivity control of ion-selective biosensors by electrophoretically mediated analyte transport. Anal Chim Acta 391:57-63

Krom MD, Sholkovitz ER (1978) On the association of iron and manganese with organic matter in anoxic marine pore waters. Geochim Cosmochim Acta 42:607-611

Krom MD, Davison P, Zhang H, Davison W (1994) High resolution pore water sampling with a gel sampler. Limnol Oceanogr 39:1967-1973

Lovley DR, Phillips EJP (1986) Availability of ferric iron for microbial reduction in bottom sediments of the freshwater tidal Potomac River. Appl Environ Microbiol 52:751-757

Luther GW III, Sundby B, Lewis BL, Brendel PJ, Silverberg N (1997) Interactions of manganese with the nitrogen cycle: alternative pathways to dinitrogen. Geochim Cosmochim Acta 61:4043-4052

Luther GW III, Brendel PJ, Lewis BL, Sundby B, Lefrançois L, Silverberg N, Nuzzio DB (1998) Simultaneous measurement of $\mathrm{O}_{2}, \mathrm{Mn}, \mathrm{Fe}, \mathrm{I}^{-}$, and $\mathrm{S}$ (-II) in marine pore waters with a solid-state voltammetric microelectrode. Limnol Oceanogr 43:325-333

Mortimer CH (1941) The exchange of dissolved substances between mud and water in lakes. J Ecol 29:280-329

Mortimer RJG, Krom MD, Hall POJ, Hulth S, Stahl H (1998) Use of gel probes for the determination of high resolution solute distributions in marine and estuarine pore waters. Mar Chem 63:119-129

Mortimer RJG, Davey JT, Krom MD, Watson PG, Frickers PE, Clifton RC (1999) The effect of macrofauna on pore-water profiles and nutrient fluxes in the intertidal zone of the Humber Estuary. Estuar Coast Shelf Sci 48:683-699

Postma D, Jakobsen R (1996) Redox zonation: equilibrium constraints on the $\mathrm{Fe}$ (III)/SO4-reduction interface. Geochim Cosmochim Acta 60:3169-3175

Sørensen J (1982) Reduction of ferric iron in anaerobic, marine sediment and interaction with reduction of nitrate and sulfate. Appl Environ Microbiol 43:319-324

Sørensen J (1987) Nitrate reduction in marine sediment: pathways and interactions with iron and sulphur cycling. Geomicrobiol J 5:401-421

Strickland JDH, Parsons TR (1972) A practical handbook of seawater analysis. Fisheries Research Board of Canada, Ottawa

Zhang H, Davison W, Miller S, Tych W (1995) In situ high resolution measurements of fluxes of $\mathrm{Ni}, \mathrm{Cu}, \mathrm{Fe}$ and $\mathrm{Mn}$ and concentrations of $\mathrm{Zn}$ and Cd in porewaters by DGT. Geochim Cosmochim Acta 59:4181-4192

Submitted: November 28, 2001 Accepted: February 19, 2002 Proofs received from author(s): May 27, 2002 